\title{
中國科樌院工業化學研究所 研究工作檢查總結
}

\section{中國科學院工業化學研究所}

我所研究人員的資産階級思想及装美思想是 普遍存在的。二年來由於领涪上米能紫緊地掌握 正確的研究方針與技術路綫，加上.多數研究技術

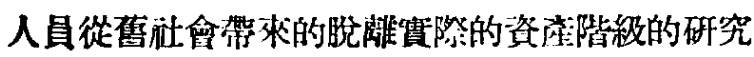
工作作風米能加以很好改進, 給研究工作造成很

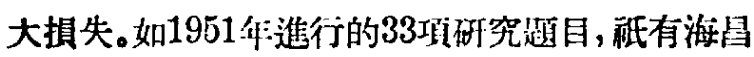
藍、氮徽素及撲痦定的研究成果可以全部或部份 工業化, 其他有的是少途而廢, 有的無法用於生產 (如块速比色定量法), 有的则只是作了些脫诺宽 際的搜集交献工作(如柔化鋁的研究), 形成了人 力、物力的巨大浪偊。

思想改造運動中在上級和黨的正確領導下粗 域了工作粗, 進行了一䢙的研究工作檢查。先由矽 嘈研究小組作了典型報告，役經领涪動員，各研究 小粗進行揭發, 批判與總結, 從而决定了各題目的 努力方向. 最後並由張大煜副所長作初步總結報 告.

通次檢查收獲具體表現在認識_上的提高與工 作上的改進。現在分六項敘述如下:

(一)閣於研究面目的選擇：過去研究題目的 决定多牛是自下而上或單純根據倜别故睡要求， 因此毛病很多, 主要表現在由個人興趣出桴。如 “氧化鋁之研究”以高矽篬原料, 題目負责人的思 想動譏是因“别人從米作過，打算一舅成名”。“拉 布達”题目負责人則是因第“解题目文践不多，做 法简單，其中一定有奥妙!”“流體化”題目負責 人對䢙方面的知識知道的很少, 郤想當“流體化專 家”，因此胡擖了五、六倜月涩有一點成績。經過檢 勆後大家都古分認識到不從客觀實際出發, 一切 要落空; 不以篇人民服務的態度從事研究工作，將 一事無成。並且也瞭解到今後題目選摆憵融是自
上而下地提出和自下而上地來䇺富內容。

(二)關於研究工作方向與门標間題: 研究工 作方向與目標的糢糊或故意会混, 過去也较多。如

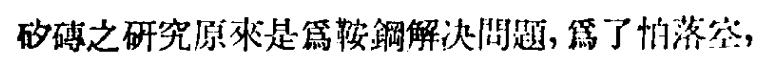
改成了“面向全國”, 結果進行了兩年, 只發表了幾 篇宾洞論文, 浪费了二境餘元。第此, 全粗间志作 了比較深刻的檢邻。又如用莱組行轉化率门標, 僅

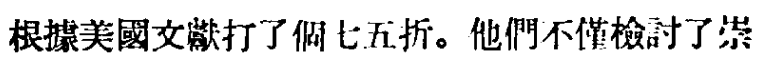
美觀念，還挖出了隐藏的“投機、保守思想”，並修 訂了計劃。

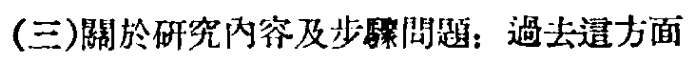

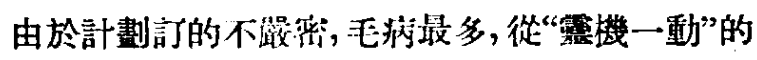
暴發户思想到“系統完整”的學院工作風樣榡都

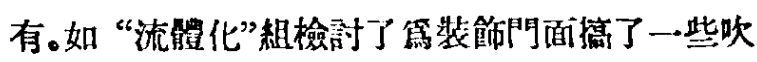
沙子實驗，花了牛和時間; 以後工作正式做了, 又

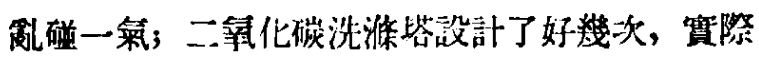
“此塔實非所篭”; 第了一些活性極低的活性炭做 了各種活化試驗, 最後才發現缷順已經生產了。

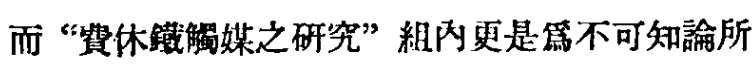
迷惑, 比如宣掦“觖媒烘製時間連一分鉝也不能坦 減”就是一偑例子。經過檢討後, 修訂了計劃, 㽗去 了一些不必要的重複工作或篇了“系統完整”而作 的排列組合研究, 計劃逐步䇸密了.

(四)關於對外聯遙工作問题: 過去浔有認識

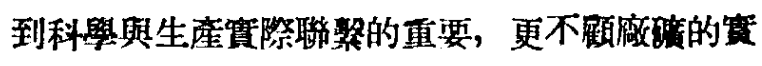
際需要，如论磚組雖然管與鞍踻聯系過三、四十 次仍未了解做砤具能情况與要求，反而對做方的 失敗抱幸桨樂禍的態度。經過此次检討,大多數研 究題目增言了對外聯獒計劃或修改了原有合同， 並組織技術人員下現微了解持况，若干題目亚與

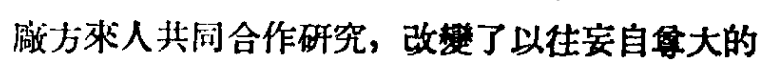


惡習。

(五)關於科學成果的推廣與工業化問題: 這 头得到了更進一步的重視。如環化組過去不考虑 工業化問題, 以篇這是上級的事, 因之忽視了好多 必要的數掉。這次增訂了計劃, 要求今年收集小型

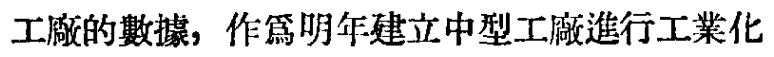
實驗的依據。“線出金岡砂”、“鋅縻提鎘”二組工作 結束後, 均到股硪推潢, 並已收到一定成續。總之 進一步肯定了我們的研究工作是要雼實際解决問 題, 要雼國家工業化提供條件, 而不是實驗實驗而 已.

（六)閣於向蘇聯學㚙問題：㯰一問題領導上 過㫖重悓也不够, 加上同志們崇美思想在作崇, 因 之有些同志根本不找蘇聯資料，有的查了資料也 是隨便試試, 抱着忽悓甚至懷疑的態度。如石墨堋

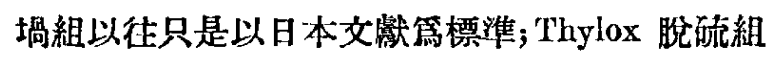
過去看了文献也不重視, 以篇“沒啥”。工作作完 了, 偶而再翻看過去不重頑的文献, 才發現文献 上不僅詳細記載了理論、數據, 甚至具體設計方法 也很完全。检討以後, 大家熱烈要求學殗俄文, 組 樴了䙵譯小組進行了交献翻譯, 並要求努力學晳 馬克思列學主義、毛澤東思想, 來清除我們在科學 認識上的鹪朽的資產階級觀點。

總的說來, 由於檢查了種種脫離筫際的工作 現象, 同志們肯定了不以主人䈳的態度來進行研
究、不認識政治領等技背的重要性是幹不好工 作的。因而要求在政治上提高的情緒空前高㜊。有 些研究室亚把提高政治認識, 把政治思想貫徹到 研究工作中去作篇具能努力方向的第一焂。

通過這一次工作與思想結合的检查, 我們得 到以下幾點經驗敉訓:

（一）重䤄執行研究工作中的經常检查制度， 是不斷提高今後研究工作質量的重要關鍵: 過去 我們會進行過一些形式上的技術檢査, 但只能解 决一些枝節問題, 甚至不能解决什麼問題。經過 這一次運動, 我們登實了、也肯定了單純技術检查 並不能提高技街質量。由於這次檢莯工作抓住和 解决工作上的思想問題, 因而把我們研究工作的 計劃性、全面性及預見性都大大提高了。

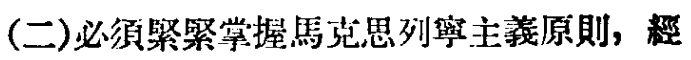
常開展批弪與自我批詐 以保證學衔思想的健康: 在通次检查過程中也有人鑽技衍牛伤尖, 經過批

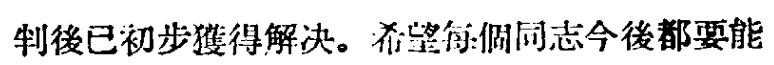
經常地緊緊地学握点克思列蜜主義, 開展批評與

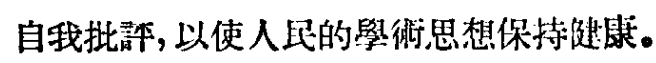

（三）检查工作一定管配合正的教育工作：道 次檢查中正面敉育工作做的不所, 因之在检查後 有些人感到空虚, 不政大胆阙屡工作, 甚至有人以 第沒有學好俄文就不能向蕉聯學澘等等, 逥都是 正面敉育做得不够的線故。

\section{[上接 45 具]}

人工; 如果只篇預防棉和和棉紅蜘蛛, 那䃬在除草 工作中應如何實現䄳除寄主植物; 如果結合預防 棉蚜來預防其他病品害, 那麼更應深入一步研究 其他有關病蛅害與雜草的關係。根㨜蘇聯先淮科

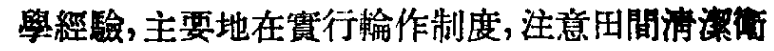
生工作, 在推行防重於治的政策以後, 望不多就君 除了害品的猖䐎,這是值得我們學習的。 